\title{
Application of graphic correlation to compare Lower Permian sections of the Glass Mountains, West Texas and the Western Slope of the Ural
} Mountains, Russia

Geology and Geophysics Department, Louisiana State University, E235 Howe-Russell Building, Baton Rouge, Louisiana 70803, Phone: 225-388-5999, E-mail: sbenoist@ hotmail.com.

\begin{abstract}
An Artinskian-Kungirian Global Boundary Stratotype Section and Point (GSSP) has been proposed for two stratigraphic intervals: the Artinskian through Kungurian stages of the western slope of the Ural Mountains, Russia, and the Leonardian Series of the Glass Mountains, West Texas. Graphic correlation applied separately to each of these intervals produced a viable composite section for the Glass Mountains Leonardian succession, whereas a composite section for the Artinskian-Kungurian succession could not be constructed within an acceptable level of confidence. In graphic correlation, selection of a standard reference section (SRS), which acts as the starting point for all succeeding graphic correlations, is an essential first step. Therefore, because the requirements for a global boundary stratotype section are essentially the same as the requirements for a SRS, it is concluded that the Arinskian-Kungirian GSSP should be established in a Leonardian section of the Glass Mountains rather than in a section from the Artinskian-Kungurian interval of the Ural Mountains.
\end{abstract}

\section{Introduction}

For the Permian System, the process of defining Global Boundary Stratotype-Sections and Points (GSSPs) is on going; and, by decision of the International Commission on Stratigraphy (ICS) and the International Union of Geological Sciences (IUGS), the Carboniferous-Permian and Lower Permian-Middle Permian GSSPs have been established in the Aidaralash section, Aqtobe region, Kazakstan and in the Stratotype Canyon section, Guadalupe Mountains, West Texas, respectively (Glenister et al., 1992). Work on establishing GSSPs for stages within the Lower Permian is in process. An important question arising from this work is whether the best global boundary stratotype section (GSS) in which to place the point defining the Artinskian/Kungurian boundary is found in the Preurals type area (western slope of the Ural Mountains) (Artinskian and Kungurian stages) or in the approximately equivalent stratigraphic interval of the Glass Mountains, West Texas (Leonardian Series) (Figures 1,2). For many researchers, this question has been answered by a decision of the International Subcommission on Permian Stratigra- phy establishing the type section of the Leonardian Series as the body stratotype of the Kungurian Stage. Many Russian researchers question this decision stating that a Kungurian GSS should be selected from sections in the Urals type area.

Considering the above, it is reasserted herein that the diversely fossiliferous Skinner Ranch through Cathedral Mountain stratigraphic interval (Leonardian Series) of the Glass Mountains, West Texas is a superior site for the establishment of an upper Lower Permian (Kungurian) GSS relative to the upper Artinskian through Kungurian stages of the Preurals, which have fewer well-documented faunal elements (Figure 3). To test this hypothesis, an attempt was made to graphically composite the existing Permian fossil range data of the Glass Mountains and Preurals sections.

The selection of a standard reference section in graphic correlation and the selection of a GSSP are similar processes in that both seek to find, within a defined chronostratigraphic interval, a stratigraphic section that, ideally, has the following characteristics: 1) a thick, continuous record of rock accumulation that is free of sedimentological and structural breaks, 2) absence of strong diagenetic and metamorphic alteration, 3) absence of broad vertical facies changes, and 4) abundant, diverse, and well-preserved fossils that exhibit short stratigraphic ranges (rapid evolution) and wide geographic ranges (international correlation potential) (Remane et al. , 1996). Figure 4 displays details of the graphic correlation technique, and further discussion of the method can be found in Shaw (1964), Edwards (1982, 1984, 1989), and Mann and Lane (1995). The GSSP selection process ends when international consensus is reached on a stratotype-section and the definition of chronostratigraphic point/s within this section. Graphic correlation differs in that, after selection

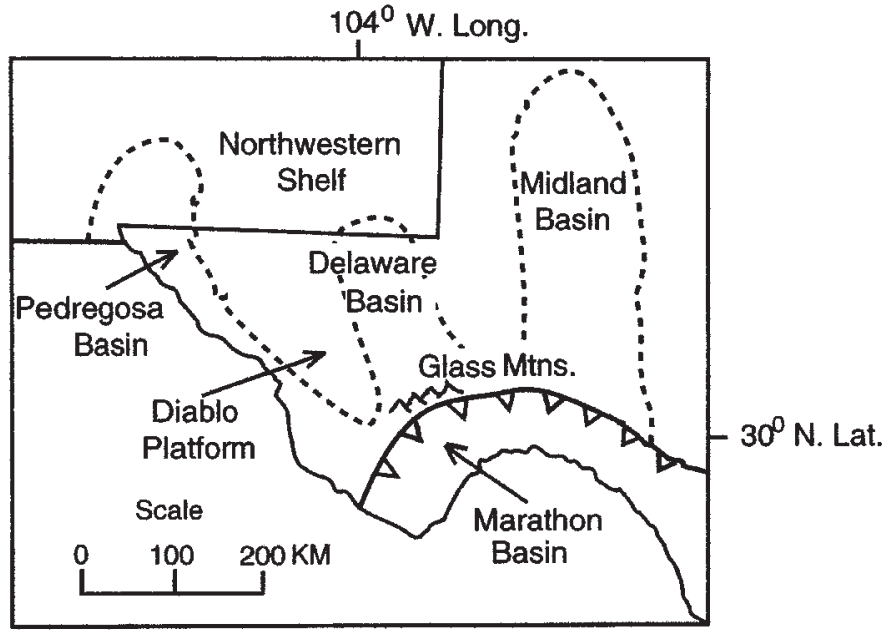

Figure 1 Location of the Glass Mountains, West Texas. 


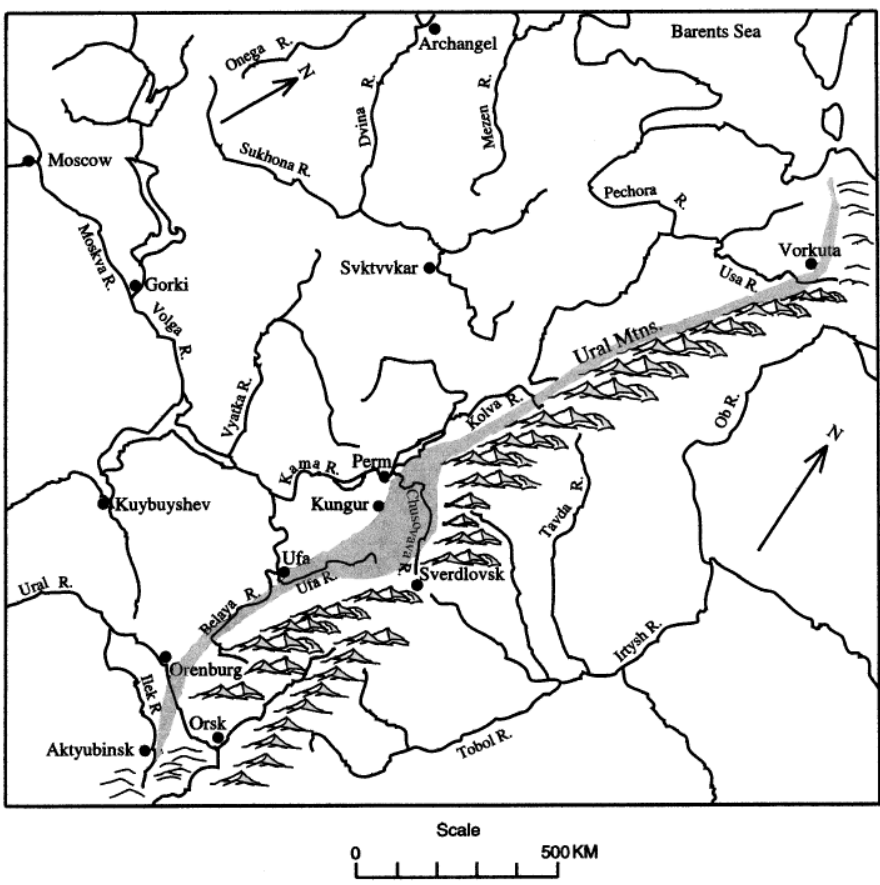

Figure 2 Approximate outcrop belt for Lower Permian strata of the western flank of the Ural Mountains, Russia.

of a stratotype or standard reference section (SRS), biostratigraphic data from temporally comparable sections are graphically composited into the SRS to give a composite section (CS), which serves as the scale on which chronostratigraphic divisions are made. Therefore, graphic correlation illustrates the correlation potential of a given stratotype section/SRS; and furthermore, the application of graphic correlation to competing type areas should clearly demonstrate their relative merit as sites for GSS selection.

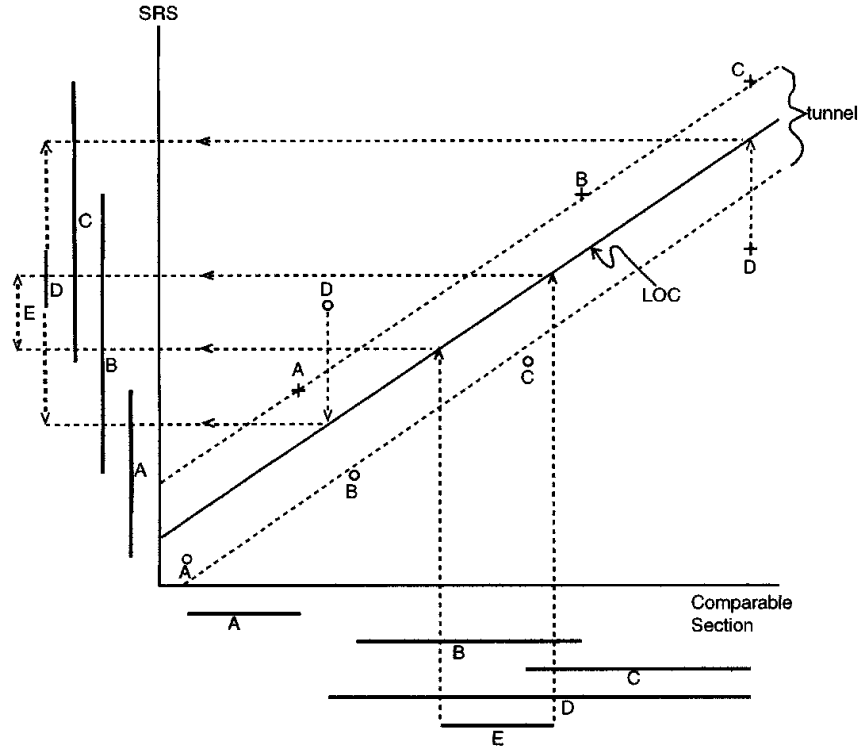

Figure 4 Graphical comparison between a hypothetical standard reference section (SRS) and a temporally comparable section. Taxa A, B, C, and D are common to both sections and their bases (o) and tops (+) plot as points on the graph. The line of correlation (LOC) fits the scatter of points so that the LOC follows the "tunnel" created among the bases and tops of $A, B$, and $C$. In the case of taxon $D$, the position of its base above the $L O C$ and its top below the LOC indicates that both the base and top of taxon D's range need adjustment in the SRS. The adjustment of range is achieved by projecting the base and top of taxon D's range on the graph into the LOC. The horizontal projections of the LOC intersection points become taxon D's new range limits in the SRS. Taxon E, which only appears in the CS, enters the SRS through the same procedure, with the horizontal projections of taxon E's LOC intersection points becoming new range data in the SRS.

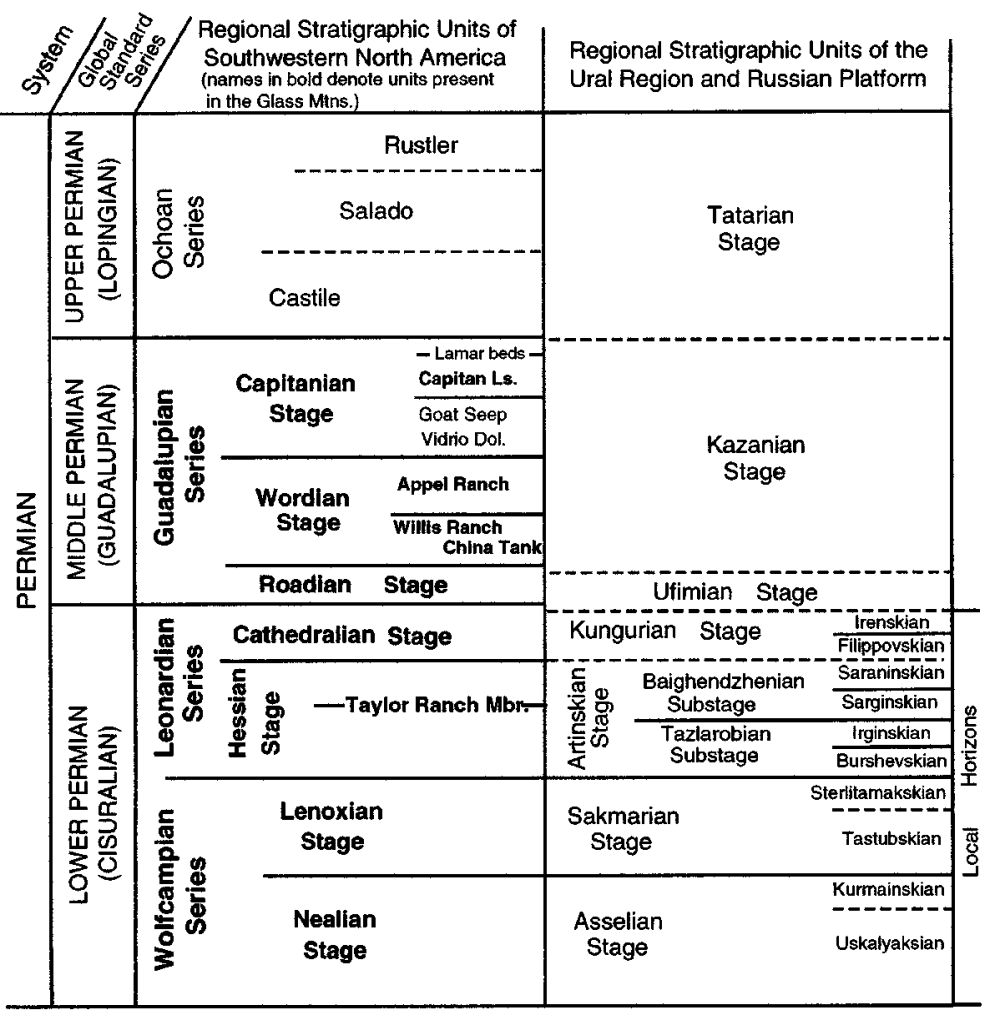

Figure 3 Permian stratigraphic units of the Glass Mountains, West Texas and the western flank of the Ural Mountains, Russia. (Modified after Ross 1994).

\section{Study design}

Completion of this study involved five steps: 1) location of key Permian stratigraphic sections in the Glass Mountains and the western Urals, 2) synthesis of the biostratigraphic data in these sections into first and last appearance range files, 3) application of graphic correlation to both the Glass Mountains and Preurals range files, 4) subdivision of any resulting composite standard (CS) in terms of established zonations, and 5) comparison of the graphic correlation process in the two study areas to help determine which area best fulfills the role of a type area for a Kungurian GSS.

\section{Application of graphic correlation to the Leonardian Series of the Glass Mountains}

\section{Location, general geology, and accessibility}

The Glass Mountains are located in Brewster County, West Texas on the northwest corner of the Marathon Basin 8 to 12 miles north of Marathon and approximately 33 miles south of Fort Stockton (Figure 5). These mountains are composed primarily of marine shale, siltstone, and limestone that dip to the northwest at approximately 10 degrees. Limestones in the Glass Mountains form several southeast-facing escarpments that tend to backstep to the northwest, whereas shales and silt- 


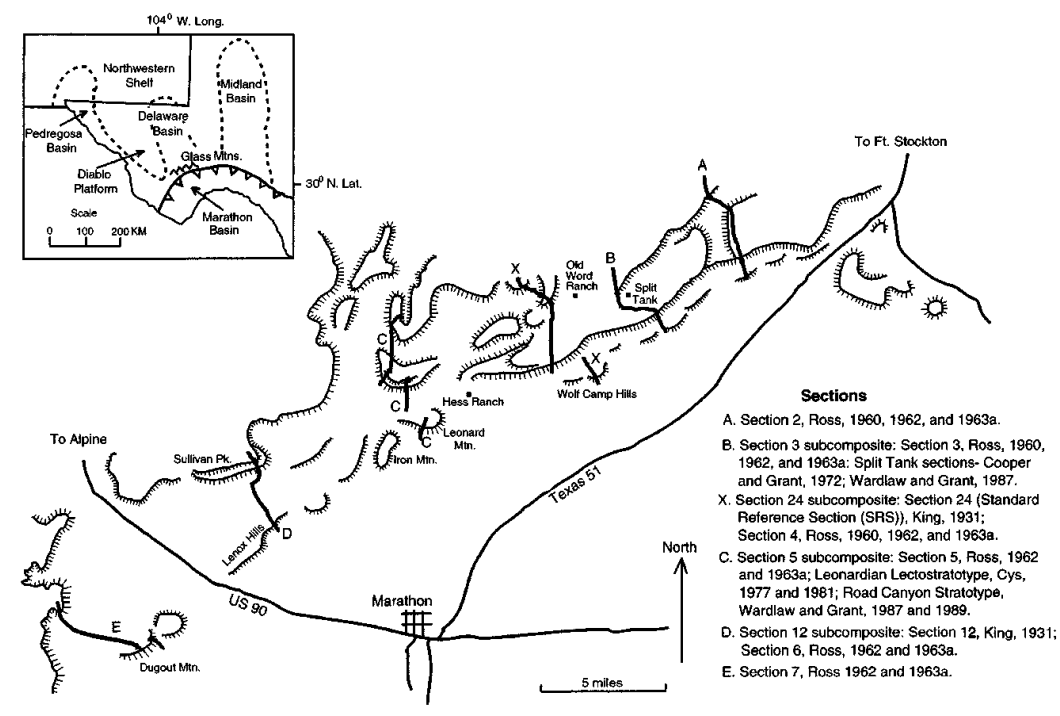

Figure 5 Location of Glass Mountains stratigraphic sections used in this study. (Modified after Ross 1962, 1963a).

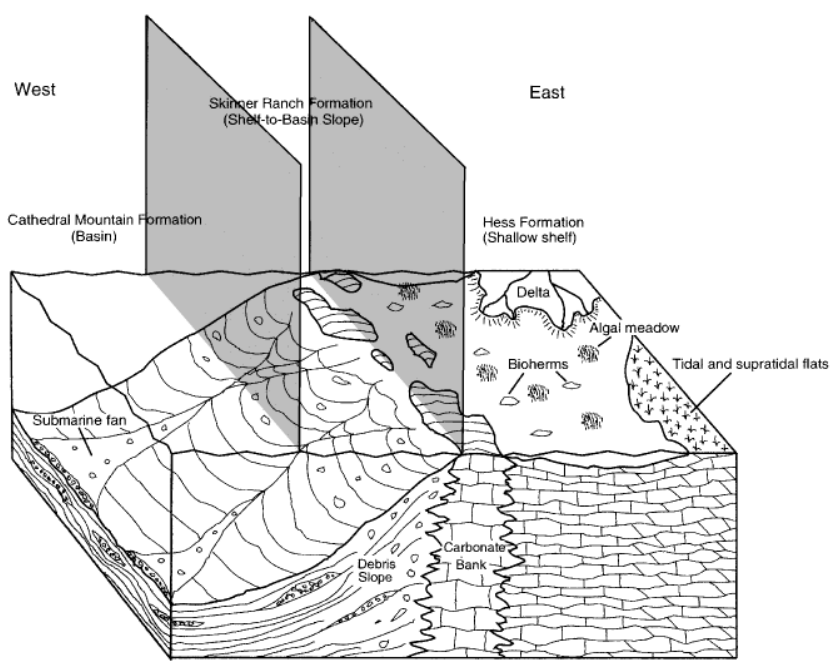

Figure 6 Inferred depositional environments along an east-west transect in the Glass Mountains. (Modified after Ross, 1987).

stones form gentle slopes and valleys between escarpments. Strata range in age from Upper Pennsylvanian (Virgilian) to Middle Permian (Guadalupian), with Permian intervals divided from bottom to top into three regional series: Lower-Permian Wolfcampian and Leonardian series, and Middle-Permian Guadalupian Series (Figure 3). Within the series and formations, Permian facies relationships are complex, but, in general, they suggest a persistent depositional trend from restricted shallow marine in the northeast to slope to basin toward the southwest (Figure 6 ). Because of excellent rock exposure and diverse biota, the Glass Mountains stratigraphic interval is considered a Lower to Middle Permian standard of reference for North America (Ross, 1963b; Cys, 1977, 1981).

The Glass Mountains are located on private ranchland, and access to various Glass Mountains sections is controlled by several land owners, many of whom are absentee landlords. Furthermore, for several years, most owners have banded together to deny (Modified after Cys, 1981). scientists land access. This fact has arisen from the owners' concern that, by allowing scientists access, it is possible that endangered species or other environmentally sensitive features will be found, and that the Federal or Texas state government will intervene to restrict the owners land use. Among the owners, biologists and environmental scientists arouse the greatest ire due to their propensity to discover endangered species, thereby inviting Federal intervention in defense of the Endangered Species Act. Geologists tend to be less threatening to some owners; but, when determining land access rights, a fine distinction among scientific "types" is not considered by the majority of owners. As of this writing, the Blakemore Ranch, which encloses the type section of the Leonardian Series and Kungurian body stratotype, is still accessible to qualified scientists.

\section{Key stratigraphic sections}

Several stratigraphic sections in the Glass Mountains are suitable for graphic correlation because they have thick, well-exposed rock successions and have an abundant, diverse biota (Figures 5, 7). These sections include P. B. King's (1931) sections 12, 17, and 24; Ross' (1960, 1962, 1963a) sections 2, 3, 4, 5, 6, and 7; Cys' $(1977,1981)$ Leonardian lectostratotype, and Wardlaw and Grants' $(1987,1989)$ Road Canyon Stratotype. Of the above authors, Ross described the fusulinacean succession and Wardlaw described the conodont succession. Also, it has been possible to incorporate taxon range data from other researchers when they recovered and described taxa from one of the above sections. These additional sources include R. E. King, 1931 brachiopods, Dunbar and Skinner, 1937 ammonoids and fusulinaceans, Cooper and Grant, 1972-1977 brachiopods, ammonoids, and fusulinaceans; Yang, 1993 fusulinaceans, and Wilde, 1995 (written communication) fusulinaceans.

\section{Compiling the Glass Mountains composite standard}

In the Glass Mountains, graphic correlation is facilitated by the fact that, although each biostratigraphic researcher has tended to concentrate on a single taxon, these researchers, in many cases, have placed their taxon appearance data in sections measured along approximately the same transect (Figure 7). Therefore, it has been possible to graphically composite these equivalent sections using lithologic
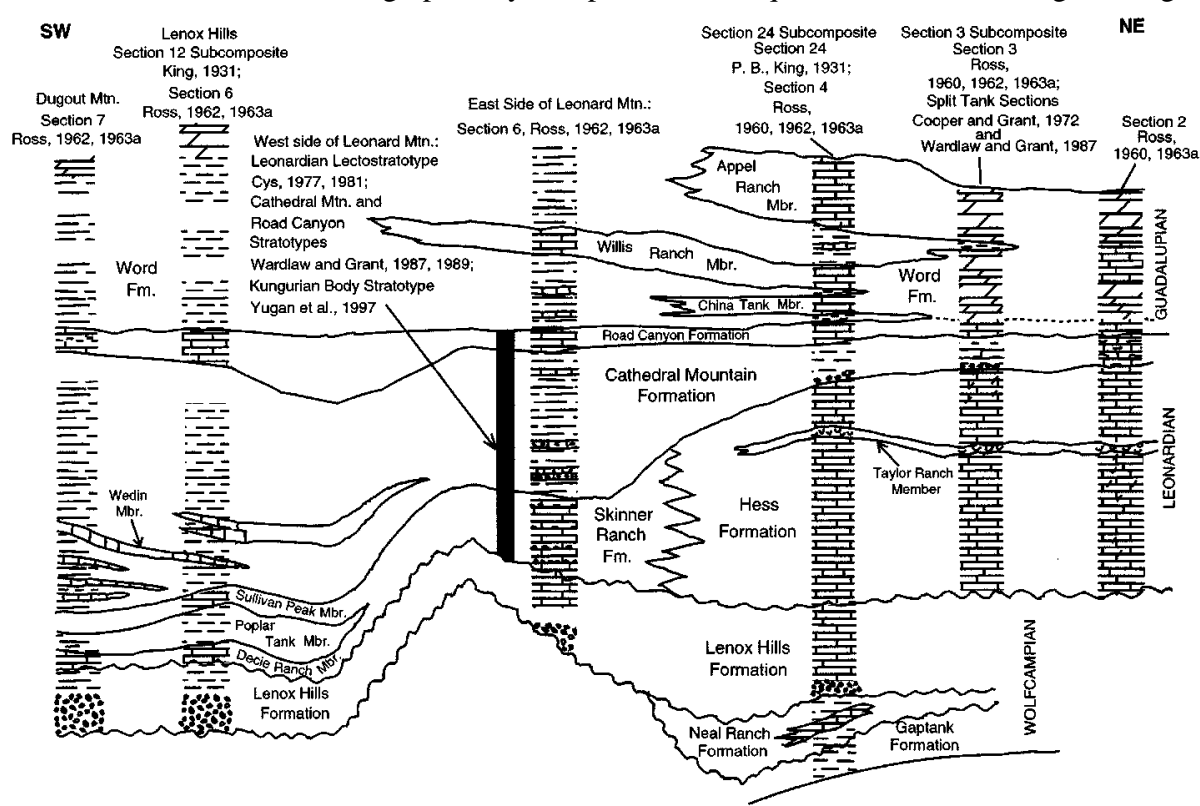

Figure 7 Lateral stratigraphic relationships in the Glass Mountains, West Texas. 


\begin{tabular}{|c|c|c|}
\hline \multicolumn{3}{|c|}{ Key } \\
\hline $\begin{aligned} \square & =\text { first appearance } \\
& =\text { last appearance }\end{aligned}$ & $\begin{array}{l}\text { Hu }=\text { Hustedia } \\
L=L \text { Lytonia }\end{array}$ & $\begin{array}{l}\text { Pen. }=\text { Peniculauris } \\
P_{r}=\text { Productus }\end{array}$ \\
\hline$\Delta=\begin{array}{c}\text { multiple first and/or } \\
\text { last appearances }\end{array}$ & $\begin{array}{l}M .=\text { Mosogondolefla } \\
\text { Ma. }=\text { Martinia }\end{array}$ & $\begin{array}{l}\text { A. }=\text { Anipidomella } \\
\text { Pro. }=\text { Prorichthotenia }\end{array}$ \\
\hline$A=$ Aclosteges & Me $=$ Moekella & $S .=S c h w a g e r i n a$ \\
\hline$C=$ Composita & Meg. $=$ Megousia & $\begin{array}{l}\text { Sc. }=\text { Schubertella } \\
S \mathrm{k}=\text { Skimmerina }\end{array}$ \\
\hline $\begin{array}{l}\text { Co. = Collematria } \\
D .=\text { Derbyia }\end{array}$ & $\begin{array}{l}N=\text { Neastraptognathodus } \\
N e=\text { Neophricadothyris }\end{array}$ & SW. $=$ Sweetina \\
\hline $\begin{array}{l}\text { Dy }=\text { Dyoros } \\
E=\text { Enteletes }\end{array}$ & $\begin{array}{l}\text { Neo. }=\text { Neospintiter } \\
P_{1}=\text { Parafusulina }\end{array}$ & $\begin{array}{l}T=\text { Torynechus } \\
X=X a n i g n a t h u s\end{array}$ \\
\hline H. $=$ Hindeodus & Pe. $=$ Perminites & \\
\hline
\end{tabular}
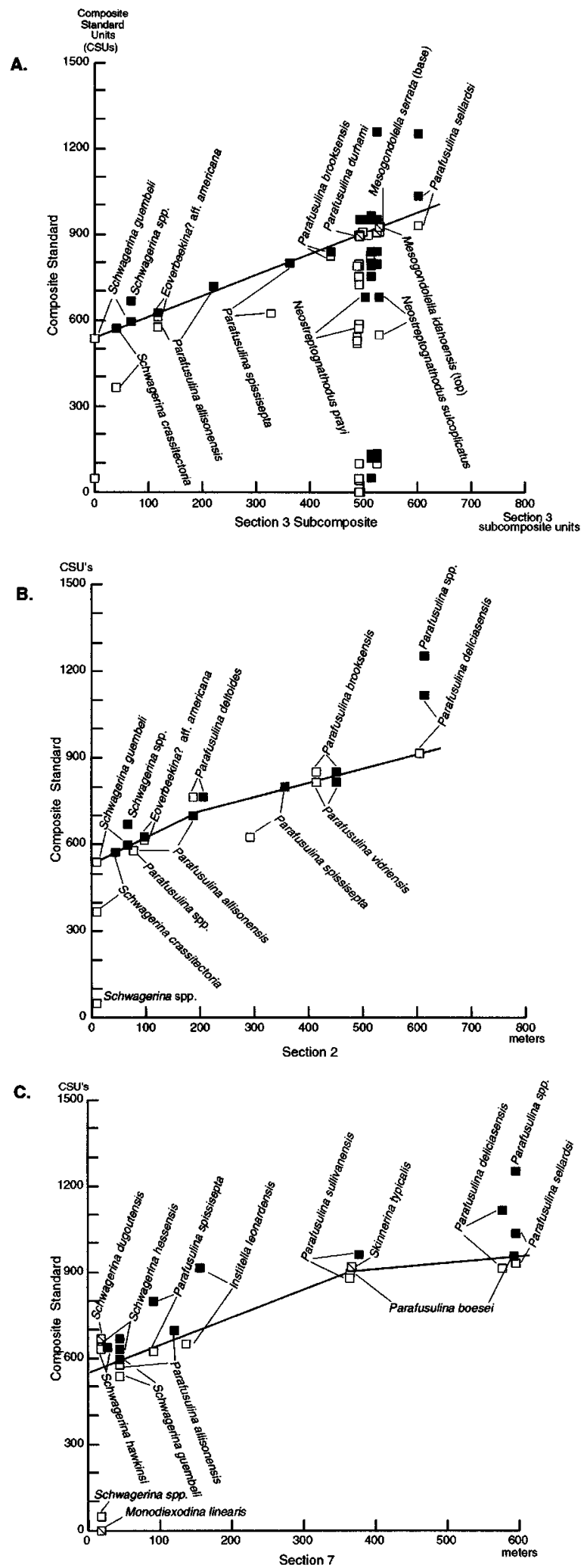

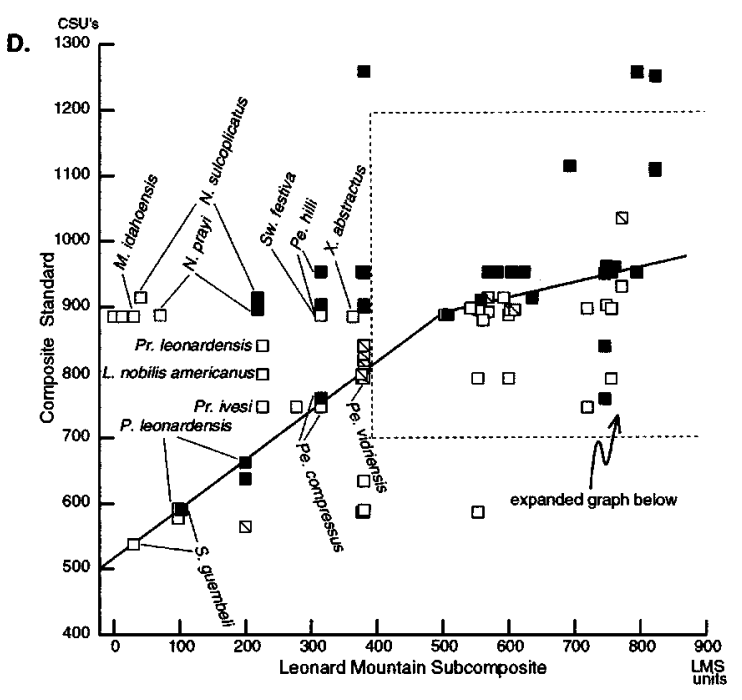

D. cont. ${ }^{\mathrm{Csu}}{ }^{1200}$

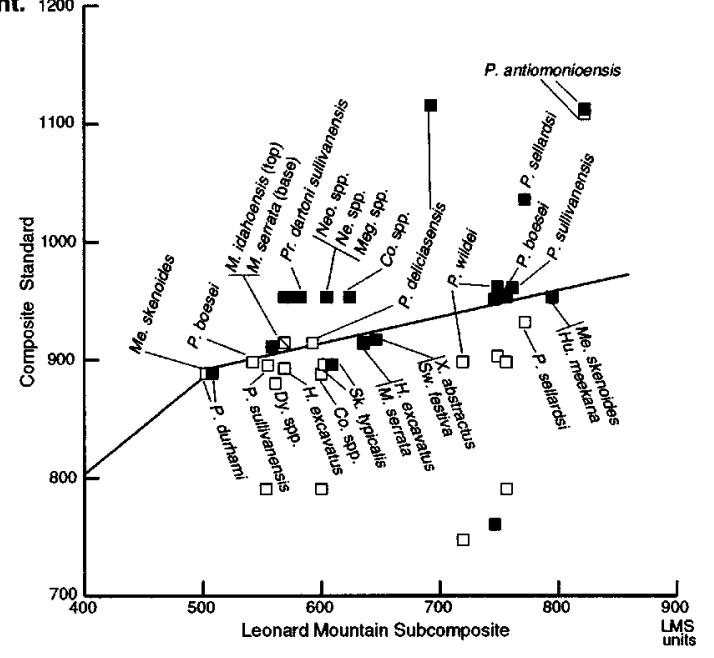

E.

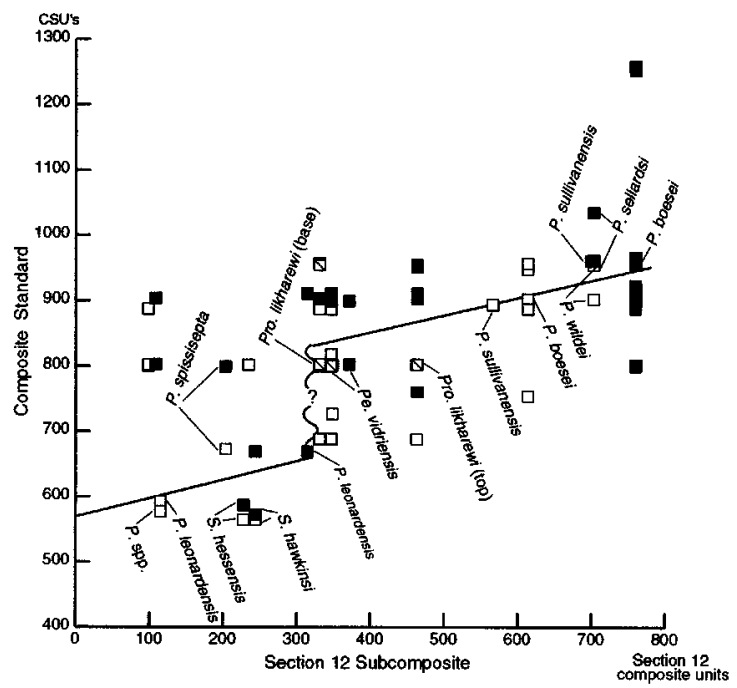

Figure 8 Fifth round graphic correlations of the Glass Mountains Composite Section versus: A-Section 3 subcomposite, B-Section 2, C-Section 7, D-Leonard Mountain subcomposite, and E-Section 12 subcomposite. 
horizons as tie points. These lithologically composited sections are designated as the: 1) Section 3 subcomposite compiled from Section 3 of Ross $(1960,1962,1963 \mathrm{a})$; and the Split Tank sections of Cooper and Grant (1972), and Wardlaw and Grant (1987); 2) Section 24 subcomposite compiled from Section 24 of King (1931), which served as the standard reference section (SRS), and Section 4 of Ross (1960, 1962, 1963a); 3) Leonard Mountain subcomposite compiled from Section 5 of Ross $(1962,1963 a)$, the Leonardian Lectostratotype of Cys $(1977,1981)$, and the Road Canyon Stratotype of Wardlaw and Grant (1987, 1989); and 4) Section 12 subcomposite compiled from Section 12 of King (1931) and Section 6 of Ross (1962, 1963a). For brevity, the process of lithologic compositing of the above sections will not be discussed, although a detailed discussion of the process can be found in Benoist (1997).

After lithologic compositing, five rounds of graphic correlation were applied to the study sections based on common first and last faunal appearance data among the sections. Multiple rounds of correlation were necessary so that lines of correlation (LOCs) for each graphic correlation could be adjusted to fit data additions and adjustments produced by subsequent graphic correlations. The recorrelation process ceased after five rounds when the positions of LOCs stabilized. Fifth round graphs are given in Figure 8.

In general, LOCs were placed to bisect the scatter of points in each graph so that a maximum number of first appearances (FAswhite squares in Figure 8) lie along or below the LOC, and a maximum number of last appearances (LAs- black squares in Figure 8) lie along or above the LOC. In addition, although biostratigraphic data from conodont, ammonoid, and brachiopod research were included in this study, the placement of LOCs was weighed to conform with fusulinacean appearances. This decision was based on the fact that, among the study taxa, fusulinaceans: 1) occur in all the study sections, 2) are abundant, 3) have a consistent stratigraphic order within sections, and 4) display a level of taxonomic consistency because the majority of fusulinacean taxa in this study were described by a single researcher (Ross, 1960, 1962, 1963a, 1964).

Apparent anomalies in data point distribution occur in the graphs of the CS versus the Section 3 and the Leonard Mountain

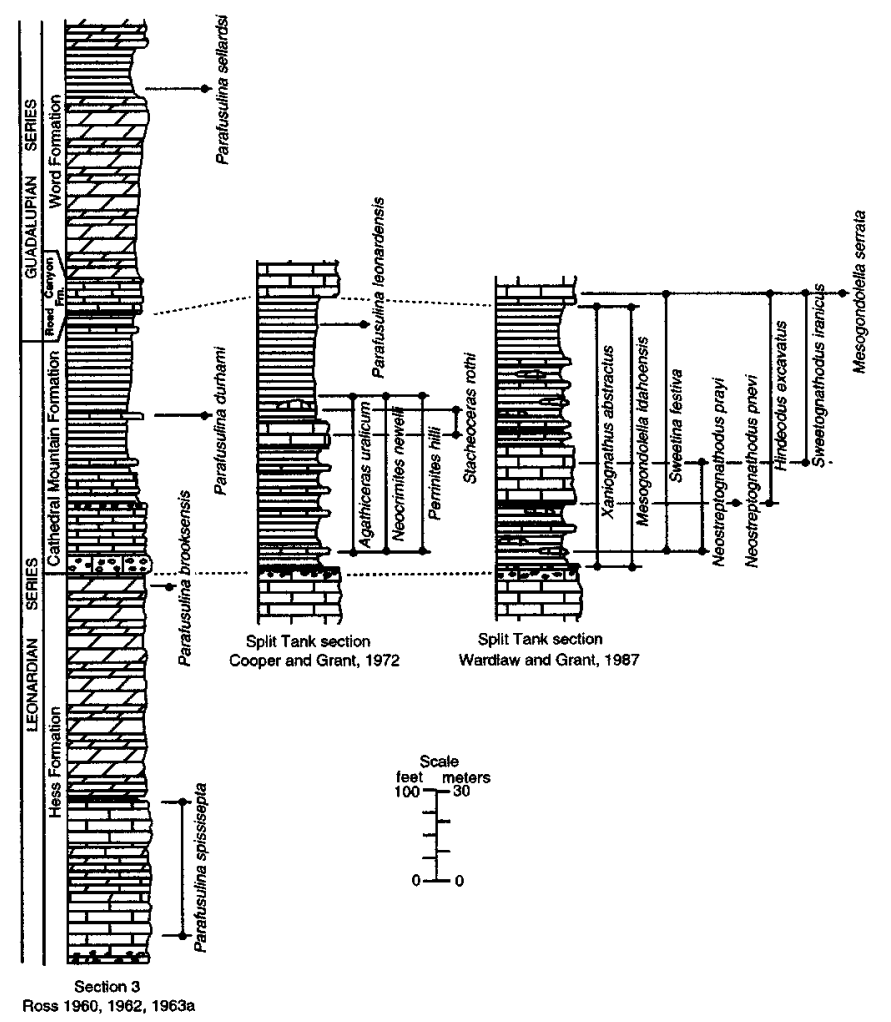

Figure 9 Lithologic correlation of the upper portion of Section 3 and the Split Tank sections of Cooper and Grant 1972; and Wardlaw and Grant 1987. subcomposite sections (Figure 8, A and D respectively). In the graph of the CS versus the Section 3 subcomposite, numerous brachiopod LAs (unlabelled black squares in the horizontal $\mathrm{x}$-axis interval between 514 to 525 units) occur well below the LOC, which has been positioned to parallel the linear trend in fusulinacean appearances; therefore, during compositing, these LAs will undergo large upward range extensions to the level of the LOC. The lack of conformity between the brachiopod and fusulinacean data patterns reflects the relatively scattered appearance of brachiopods among the study sections, with the LAs of these taxa tending to be truncated in the CS relative to the Section 3 composite. Conversely, the vertical alignment of brachiopod FAs (unlabelled white squares at approximately 492 on the $\mathrm{x}$-axis) below the LOC indicates that the FAs of these taxa are truncated in the Section 3 subcomposite relative to the CS. In the graph of the CS versus the Leonard Mountain subcomposite, several taxon FAs occur well above the LOC ( $\mathrm{x}$-axis interval between 0 to 400 units) and do not conform to the fusulinacean data pattern; therefore, during compositing, these FAs will undergo large downward range adjustments to the LOC level. This anomaly results from the fact that CS FAs of these taxa were first established by studies (Cooper and Grant, 1972; Wardlaw and Grant, 1987) in which sampling was limited to the relatively thin Cathedral Mountain Formation in the Split Tank area (Figure 9); therefore, the LOC suggests that these anomalous CS FAs are highly truncated.

Another feature apparent during graphic correlation is the pronounced decrease in upper LOC slope (Road Canyon and Wordian intervals) occurring in the graphs of the CS versus Section 7 and the Leonard Mountain subcomposite (Figure 8, C, D). This decrease in slope suggests a decrease in the rate of CS rock accumulation relative to Section 7 and the Leonard Mountain subcomposite.

\section{Glass Mountains composite section}

The Glass Mountains CS contains the complete biostratigraphic data set (795 taxa) for Wolfcampian through Roadian strata of the Glass Mountains study sections. Also, the CS contains any extensions of taxon ranges that occurred during graphic correlation (See Figure 4 for details of the range extension process). Listed in order of decreasing numbers of species in the CS, the CS taxa belong primarily to four groups: brachiopods, fusulinaceans, conodonts, and ammonoids. Within these groups, taxon range limits have an inherent level of uncertainty; and, among the study sections, those taxa that are most common among the sections should have ranges closer to true stratigraphic ranges (Shaw, 1964). Also, many taxon ranges in the CS are probably underestimates. This probability derives primarily from two factors: 1) the facies-controlled distribution of most species employed in this study, and 2) the restriction of data recovery to measured stratigraphic sections. In the case of ammonoid and brachiopod appearance data, the second factor is accentuated because many of the existing appearance data are recorded at map localities and are not placed in measured stratigraphic sections (A comprehensive summary of Permian biostratigraphic data of the Glass Mountains, inclusive of appearances not placed in measured stratigraphic sections, is presented by Wardlaw, 1996).

The ranges of CS taxa are summarized in Figure 10. In this range chart, only those taxon ranges that are important in the delineation and subdivision of the Leonardian Series (Artinskian-Kungurian stages) are illustrated (Discussion of the criteria used to produce the zonation presented herein can be found in Benoist, 1997). Also, resulting from factors discussed in the previous paragraph, the uncertainty attaining to taxon ranges is illustrated by: 1) placing relatively wide gray lines between biostratigraphic subdivisions, 2) noting after each taxon's name its total number of appearances among the sections, and 3) indicating those CS taxon ranges that conflict significantly with published zonal schemes within the southwestern United States.

Using the CS as an objective standard, Figure 11 illustrates the relative stratigraphic positions and the inferred lateral facies relationships among the study sections. The facies relationships are essentially the same as those presented by Cys 1981 (Figure 7) 

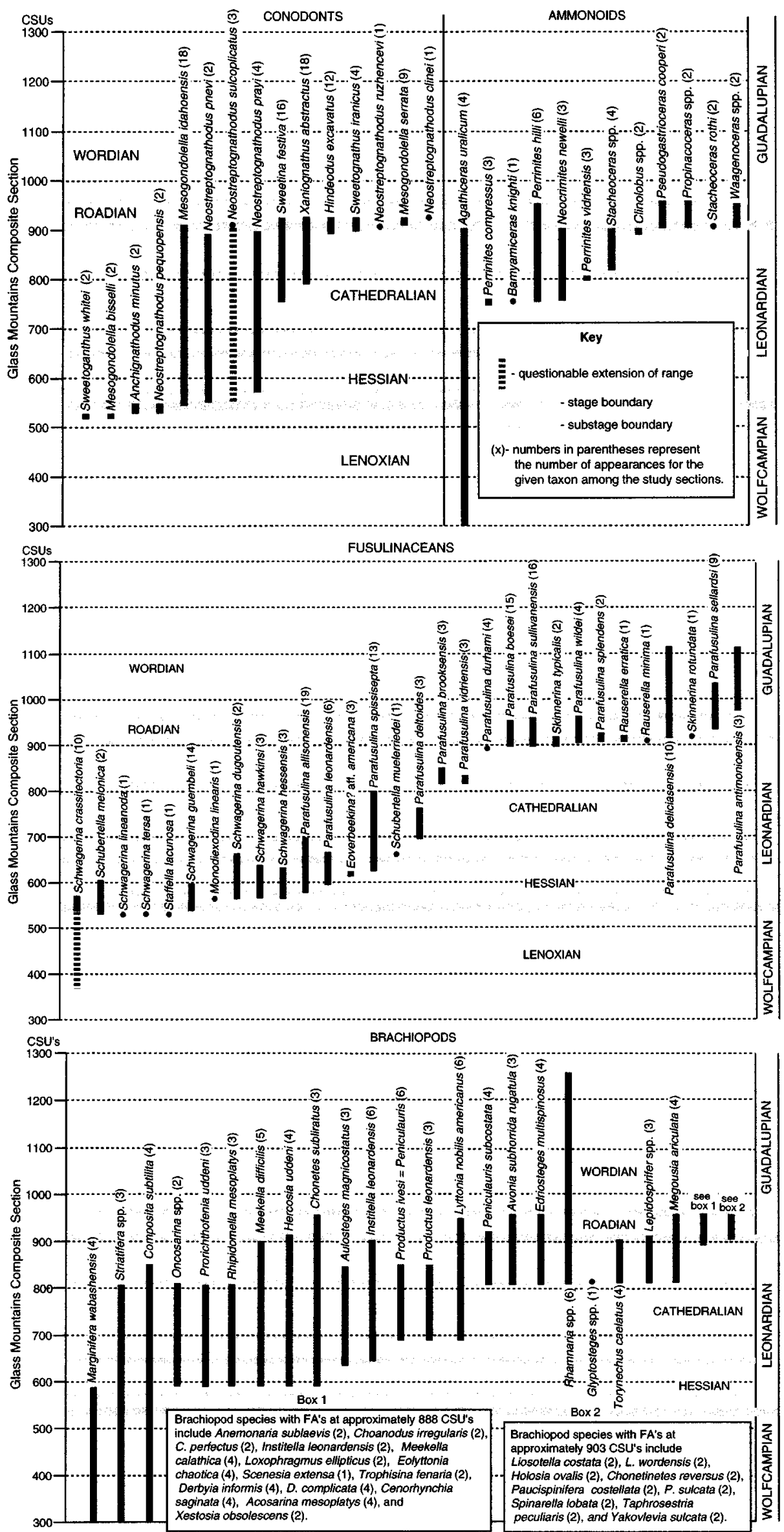

Figure 10 Range chart for selected taxa in the Glass Mountains Composite Section with proposed stages and substages. except that in Figure 11 the Cathedral Mountain, Skinner Ranch, and Hess formations are portrayed as contemporaneous facies for an extensive CS interval (approximately 650 to 800 composite standard units (CSUs)).

\section{Application of graphic correlation to Artinskian/Kungurian sections of the western slope of the Urals (Preurals)}

\section{Location and general geology}

Type sections for the Lower Permian are located in the western foothills of the Ural Mountains (Preurals) which extend from Novaya Zemlya in the north to Aktyubinsk (Aktöbe) in the south (Figure 12). The Ural Mountains formed during the Late Carboniferous to Early Permian due to the suturing of the Euramerican and Angara plates. Westward of the center of Uralian orogenesis, an asymmetric foreland basin developed in which accumulated a thick marine succession of Upper Carboniferous through Permian rocks (Figure 13). The eastern portion of the basin is dominated by a thick succession of terrigenous clastic sediments derived from the Ural Mountains, whereas, to the east, these sediments thin and tend to be progressively replaced by carbonates and evaporites. Upward, the basin succession becomes increasingly restricted marine to terrestrial in character, with the Kungurian Stage being noted for its evaporite deposits. After deposition, the basin sediments acquired varying degrees of folding and faulting as they became involved in the final stages of Uralian orogenesis (Dunbar, 1940; Nalivkin, 1962; Khain, 1985).

\section{Key stratigraphic sections}

Stratigraphic sections from the western Urals selected for this study include: 1) from the southern Preurals, the Kondurovsky I and II, Dalny Tulkas River, and Syryat sections, 2) from the central Preurals, the Burtsevka, Sarana, Sarga River, Berdym, Arti, Novaya Derevnaya, Chikali, Sverdlovskoi Railroad, Ledyanaya Gora, Sylva River, and Podkamennoye sections, 3) and from the polar Preurals, the Kozhim River section (Figures 12, 14). The biostratigraphic data for these sections have been acquired primarily from four sources: 1) the Permian Working Group at Boise State University (Dr. Claude Spinosa chairman), who kindly allowed me to access their faunal data set from the Urals, 2) Earth Sciences and Resources Institute 


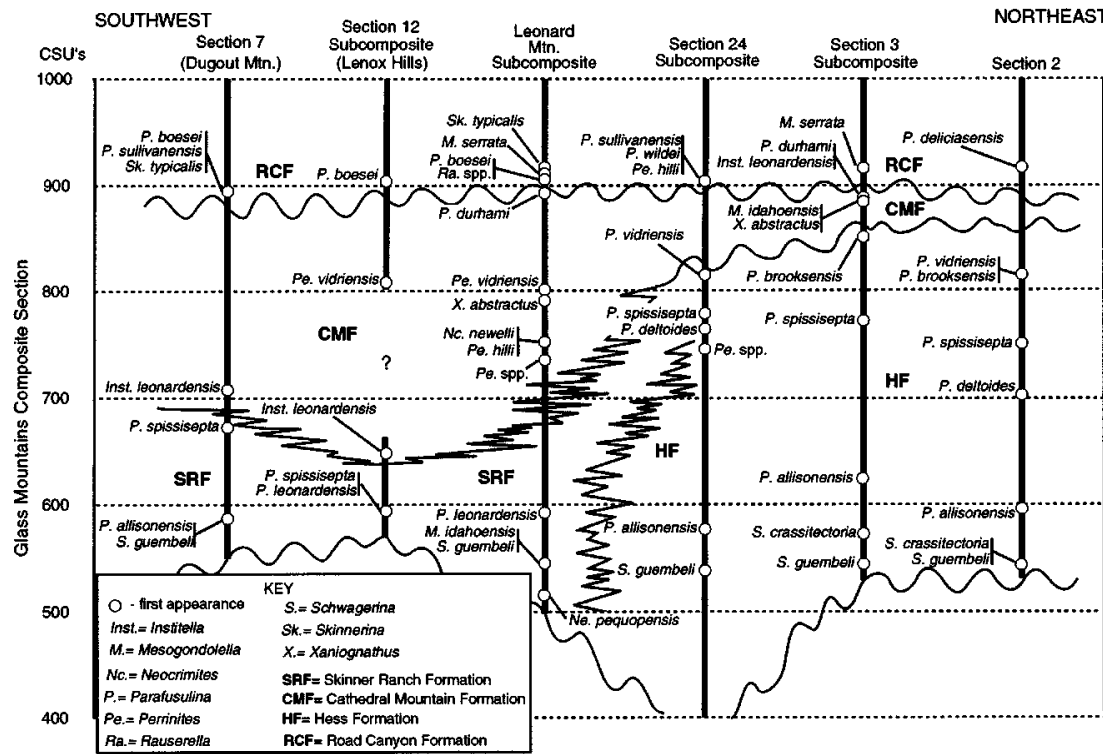

Figure 11 Inferred facies relationships with first appearances of key taxa among the study sections.

$$
\text { WEST }
$$

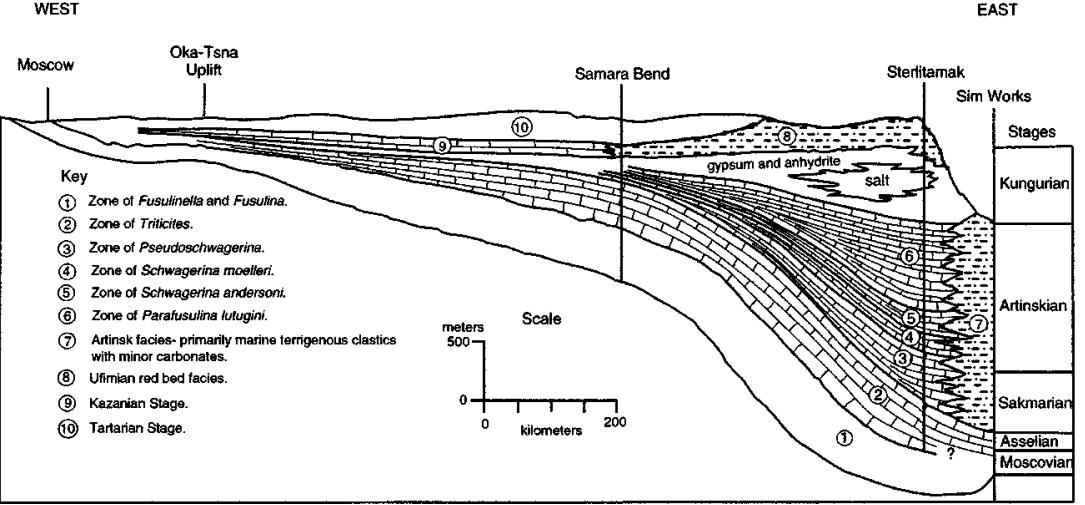

Figure 12 Generalized cross-section of Upper Carboniferous and Permian strata from the Urals foreland basin (west) to the Russian platform (east). (Modified after Dunbar, 1940).

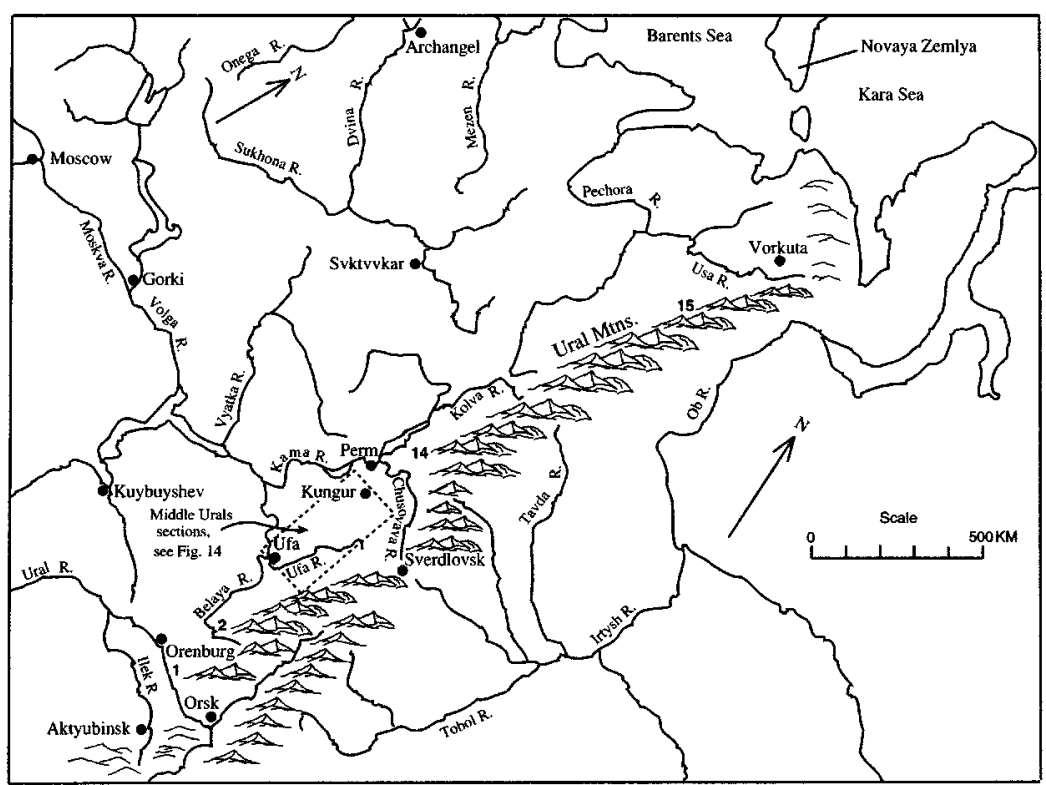

Figure 13 Artinskian-Kungurian sections of the western Urals: 1) Kondurovsky I and II, and Dalny Tulkas, 2) Syryat, 3-13) middle Urals, see Figure 14; 14) Belaya Gora, Karpikha, and Rassolny; and 15) Kozhim River.
Occasional Publication Number 10 (Coyner et al., 1993), 3) Opornye Razrezy Verkhnego Karbona I Nizhnei Permi Zapadnogo Sklona Urala I Priuralya (Chuvashov, 1990), and 4) Osnovnye Cherty Stratigrafii Permskoi Sistemy SSSR (Kotlyar and Stepanov, 1984).

\section{Suitability of graphic correlation when applied to Artinskian/Kungurian sections of the Preurals}

Prior to graphic correlation, the Preurals study sections were positioned in their approximate chronostratigraphic order (Figure 15) based on generally accepted biostratigraphic succession established in published studies (Figure 16). A general feature of this order is the gradual upward decline in the appearances of conodonts, fusulinaceans, and ammonoids with correlation of sections in the Kungurian interval relying primarily on appearances of ostracods, nonfusiform foraminifera, brachiopods, pelecypods, and palynomorphs. This faunal transition reflects the fact that upward in the Artinskian-Kungurian interval paleoenvironments become increasingly restricted-marine to terrestrial in character. Another feature evident in Figure 15 is the relatively limited chronostratigraphic extent of most of the study sections with limited or no overlap between many of the sections. Only the Kozhim River and Dalny Tulkas sections are reported to have strata representative of the complete study interval.

Preliminary graphic comparisons among the Preurals study sections showed that the Kozhim River and Dalny Tulkas sections have the greatest number of common data points (Figure 17). In this comparison, it was not possible to place an LOC with an acceptable level of confidence. Difficulty in placing a LOC results from three factors: 1) the wide dispersion among the graph data points 2) the segregation of points into discrete clusters, and 3) the intermixing of bases and tops within the graph area. To a large degree, these factors

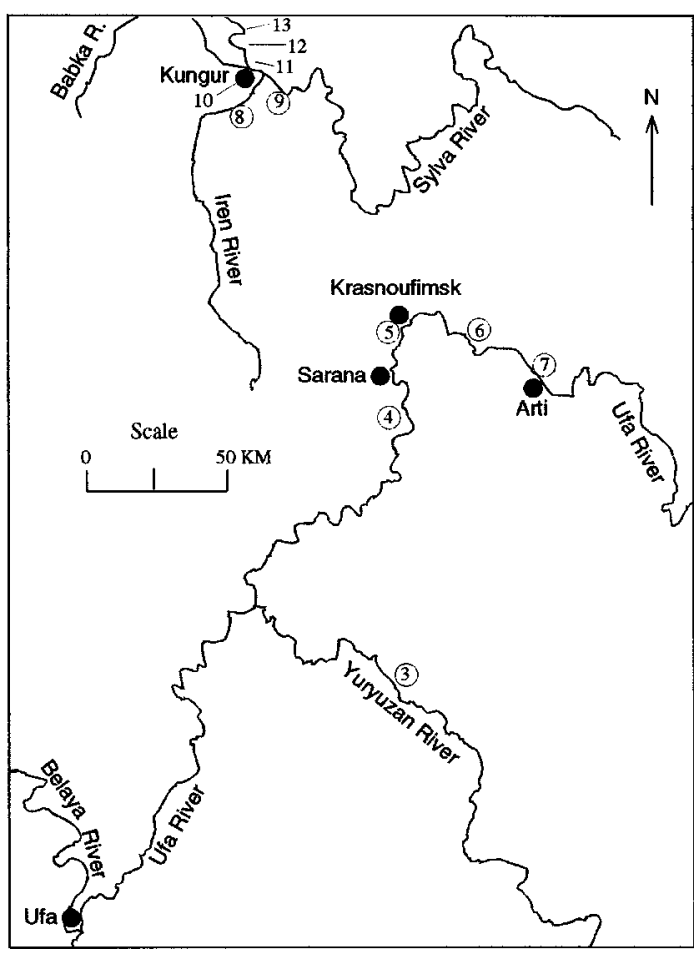

Figure 14 Artinskian-Kungurian sections of the middle Urals. 


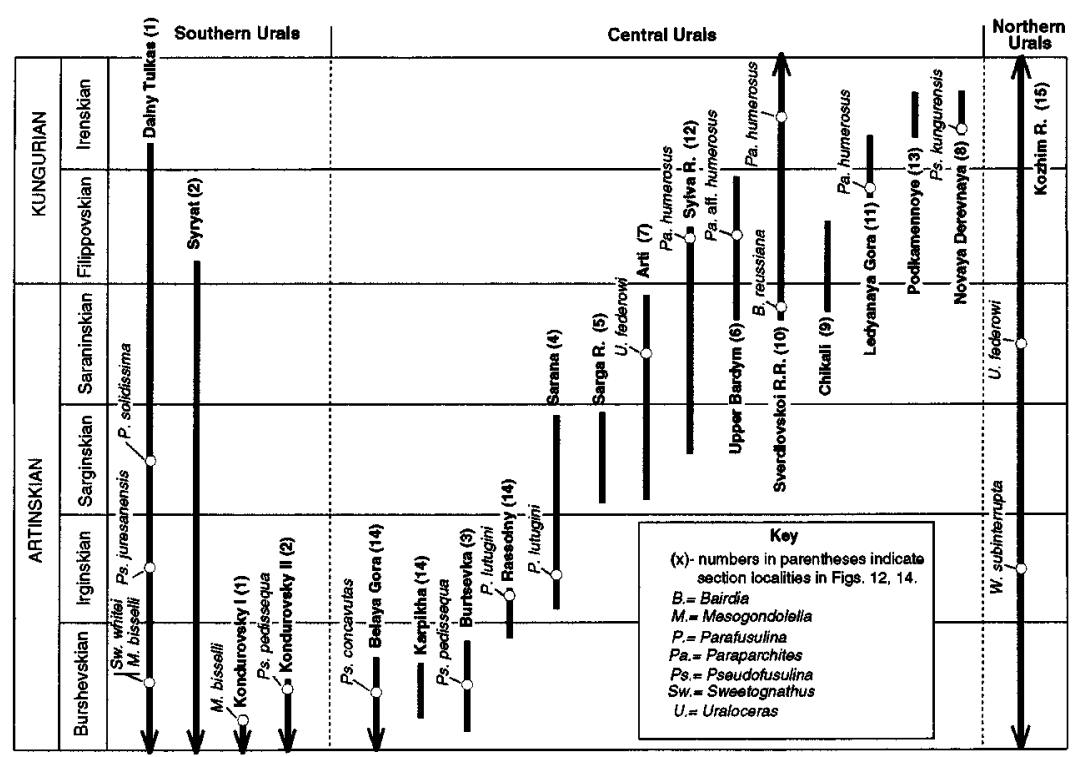

Figure 15 Approximate chronostratigraphic position of Artinskian/Kungurian sections Preurals.

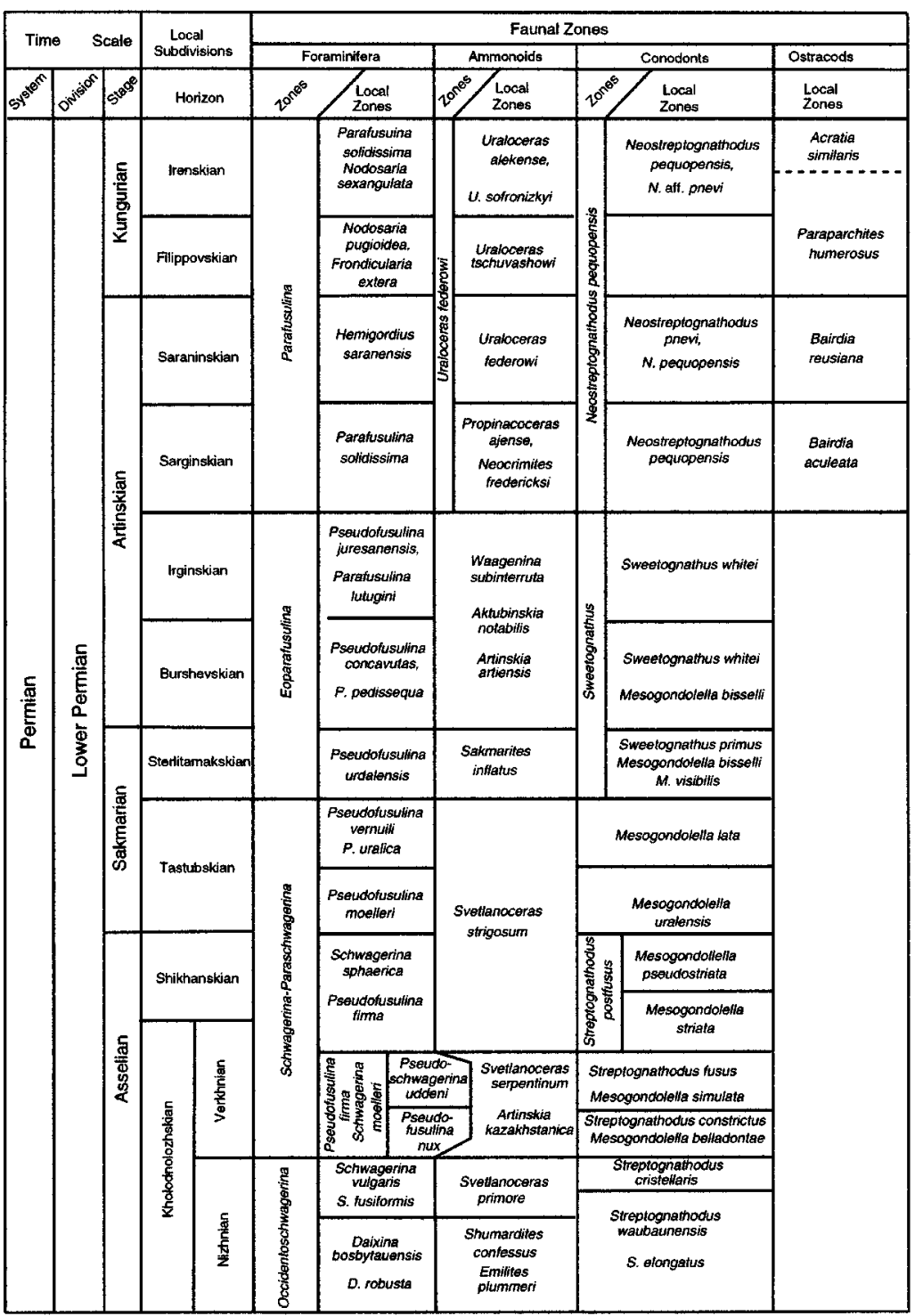

Figure 16 General stratigraphic and biostratigraphic divisions of Lower Permian strata along the western slope of the Ural Mountains. (From Chuvashov et al. , 1990; Coyner et al. , 1993). reflect the upward facies transition from strata containing conodonts, fusulinaceans, and ammonoids to strata dominated by brachiopods, ostracods, and palynomorphs. As can be seen in Figure 17, the LAs of the ammonoids Paragastrioceras spp. and $P$. jossae, and the fusulinids Pseudofusulina urdalensis and Parafusulina spp. fall in the lower half of the graph, whereas the FAs of several palynomorph taxa (Leiosphaeridia spp., Vesicaspora spp., Limitisporites spp., Cyclograniosporites spp., Cordaitina uralensis, Striatopodocarpites alatus, and Striatodiplopinites striatus) fall in the upper half of the graph. This observation is consistent with a general change from marine to restricted-marine and terrestrial paleoenvironments, and it is likely that LAs of marine taxa, and the FAs restricted-marine and terrestrial taxa are highly truncated relative to their true stratigraphic appearances. A LOC positioned to roughly divide FAs from LAs and to produce relatively conservative range adjustments can be placed on the graph (dashed line A), but compilation into the $y$-axis using this LOC projects the LA of Triticites spp. into the Kungurian of the Kozhim River section. This projection of the LA of Triticites is much higher than the highest reported LA of Triticites in Sakmarian strata. It is likely that a LOC approximating the time relationship between the two sections has a negative y-intercept (dashed line B), although the graph data points give little evidence to support this conclusion. From the above discussion, it is evident that graphic correlation is not applicable to the Preurals biostratigraphic data set employed in this study.

\section{Conclusion}

The application of graphic correlation to Upper Lower Permian type sections of the Glass Mountains and western Urals (Leonardian and Artinskian/Kungurian respectively) resulted in a viable CS for the Glass Mountains, whereas the Urals type sections could not be composited with an acceptable level of confidence.

In the Glass Mountains, graphic correlation was facilitated by the facts that all study sections: 1) extend across the study interval and are in objective stratigraphic position relative to the overlying Guadalupian Series, 2) are dominated throughout their width by rocks representative of marine paleoenvironments, and 3) have a comparable fauna that contains abundant representatives of rapidly evolving and geographically wide ranging marine groups such as conodonts, fusulinaceans, and ammonoids. Furthermore, species descriptions and range data for key conodont and fusulinacean taxa were obtained primarily from Wardlaw and Grant (1987, $1989)$ and Ross (1960, 1962, 1963a) respectively; therefore, these taxa were consistently described among the study sections. Negative factors include the facts that the Glass Mountains SRS and other study sections contain major breaks in rock accumulation (Ross 1987; Ross and Ross, 1994), and that many of the Glass Mountains sections are not accessible to scientific researchers, although, as of this writing, the type area for the Leonardian Series (Cys' Lectostratotype) is still open to qualified researchers.

The inability to graphically correlate the Artinskian/Kungurian sections of the western Urals results primarily from three factors: 1) the study sections stretch over a wide area; therefore, endemism is an important factor especially when comparing southern versus northern sections, 2) in many cases, sections are thin and lack significant biostratigraphic overlap with the other study 
sections (Figure 15), and 3) in those sections that extend across the study interval (Kozhim River and Dalny Tulkas), biotas representative of marine paleoenvironments are progressively replaced by biotas representative of restricted marine to terrestrial paleoenvironments (Figure 17). Factor 3 results in the truncation of the LAs of marine taxa, and the FAs of restricted-marine and terrestrial taxa; and, in graphic comparisons, these truncations will lead to a concentration of data points centered on the paleoenvironmental change which is probably a diachronous event among the study sections.

Therefore, for the reasons discussed above, the inability to graphically correlate the study sections of the western Urals suggests that the Artinskian-Kungurian GSSP should not be placed in one of these sections. Whereas, for study sections of the Glass Mountains, the relative ease with which graphic correlation can be applied supports the ISPS' decision to eventually establish the Artinskian-Kungurian GSSP in the Leonardian type section (Cys' lectostratotype). (It should be noted that, although Section 24 (P. B. King, 1931) served as the SRS for purposes of graphic correlation, this section is not suitable as a GSSP because it is located on private property that is presently closed to scientists.) These conclusions must be tempered by the fact that the Russian literature was not researched as thoroughly as the Glass Mountains literature due mainly to the authors limited knowledge of the Russian language. Therefore, an important future refinement of this research will involve further exploration of the western Urals biostratigraphic data.

\begin{tabular}{|c|c|}
\hline \multicolumn{2}{|l|}{ KEY } \\
\hline $\boldsymbol{\sigma}=$ last appearance & $L m .=$ Limitisporites \\
\hline$\square=$ first appearance & $P .=$ Parafusulina \\
\hline$\Phi=$ multiple bases and/or tops & $P a .=$ Paragastrioceras \\
\hline$A z=A z o n a l e t e s$ & $P s .=P$ seudofusulina \\
\hline Cor $=$ Cordaitina & $P s c .=P$ seudocircella \\
\hline$C y .=$ Cyclograniosporites & Std $=$ Striatodiplopinites \\
\hline En $=$ Entylissa & Sth $=$ Striatohaplopinites \\
\hline Fl. $=$ Florinites & Stp. $=$ Striatopodocarpites \\
\hline Hm. $=$ Hamiapollenites & $T r .=$ Triticites \\
\hline Lei. $=$ Leiosphaeridia & Ur.= Urmites \\
\hline & $V \cdot=$ Vesicapora \\
\hline
\end{tabular}

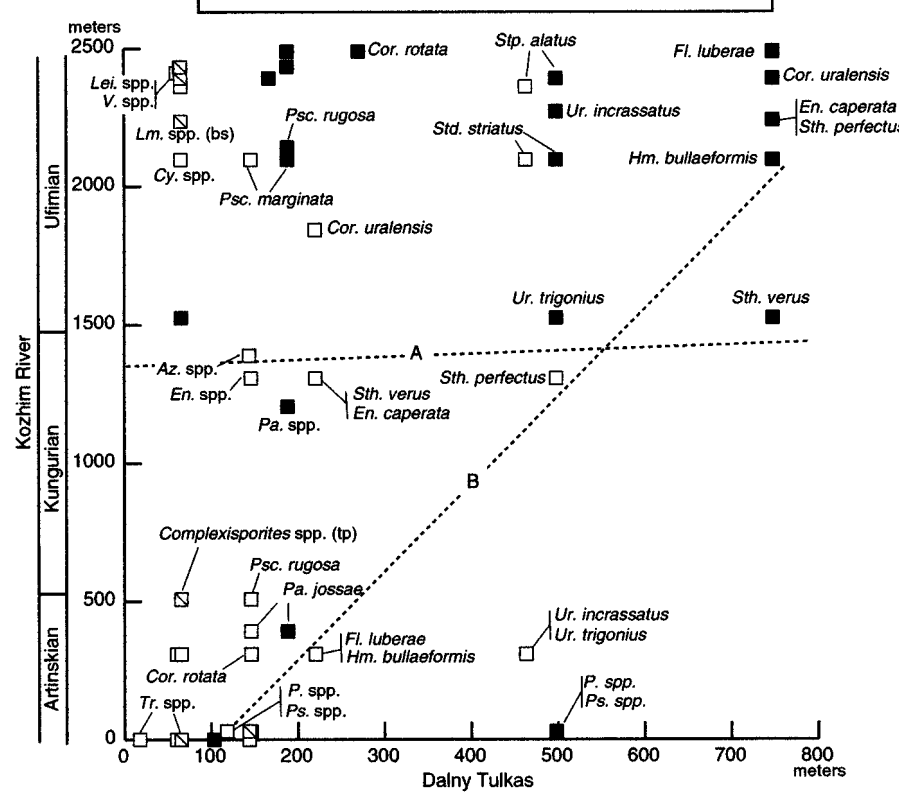

Figure 17 Graphic correlation of the Kozhim River and Dalny Tulkas sections.

\section{References}

Benoist, S. L., 1997, Application of graphic correlation to upper Lower Permian (Artinskian-Kungurian) stratigraphic sections of the Glass Mountains, West Texas and the western slope of the Ural Mountains, Russia: Unpublished Ph.D. dissertation, The University of Iowa, Iowa City, $241 \mathrm{p}$.
Benoist, S. L., 1998, Graphic correlation applied to Lower Permian stratigraphic sections of the Glass Mountains, West Texas: Permophiles, no. 32, pp. 24-32.

Chuvashov, B. I., Dyupina, G. B., Mizens, G. A., and Chernykh, V. V., 1990, Opornye Razrezy Verkhnego Karbona I Nizhnei Permi Zapadnogo Sklona Urala I Priuralya: Sverdlovsk, Uro An SSSR, 369p.

Cooper, G. A. and Grant, R. E., 1972, Permian Brachiopods of West Texas, Part I: Smithsonian Contributions to Paleobiology, no. 14, pp. 1-230.

Cooper, G. A., and Grant, R. E., 1977, Permian Brachiopods of West Texas, Part VI: Smithsonian Contributions to Paleobiology, no. 32, pp. 31613370.

Coyner, C. C., Prynne, C. M., Render, J. M., and Shervais, M. ,eds., 1993, Permian System: Guides to geological excursions in the Uralian type localities: Occasional Publications Earth Sciences and Resources Institute, New Series, No. 10, University of South Carolina, Columbia, South Carolina, 303p.

Cys, J. M., 1977, Lectostratotype of North America Leonardian Series, Glass Mountains, west Texas: Geological Society of America Abstracts with Programs, v. 9, pp. 14.

Cys, J. M., 1981, Preliminary report on proposed Leonardian lectostratotype section, Glass Mountains, West Texas: Symposium and Guidebook, 1981 Field Trip, Permian Basin Section, Society of Economic Paleontologists and Mineralogists, pp. 183-205.

Dunbar, C. O., 1940, The type Permian: its Classification and Correlation: Bulletin of the American Association of Petroleum Geologists, v. 24, pp. 237-281.

Dunbar, C. O., and Skinner, 1937, Permian Fusulinidae of Texas: The Geology of Texas: University of Texas Bulletin, 3701, pp.519-825.

Edwards, L. E., 1982, Quantitative biostratigraphy: the method should suit the data, in Cubitt. J. M., and Reyment, R. A., eds., Quantitative Stratigraphic Correlation, John Wiley and Sons, pp. 45-60.

Edwards, L. E., 1984, Insights on why graphic correlation (Shaw's Method) works: Journal of Geology, v. 92, pp. 583-597.

Edwards, L. E., 1989, Supplemented graphic correlation: a powerful tool for paleontologists and nonpaleontologists: Palaios, v. 4, pp. 127-143.

Glenister, B. F., Boyd, D. W., Furnish, W. M., Grant, R. E., Harris, M. T. Kozur, H., Lambert, L. L., Nassichuk, W. W., Newell, N. D., Pray, L. C., Spinosa, C., Wardlaw, B. R., Wilde, G. L., and Yancey, T. E., 1992, The Guadalupian: proposed international standard for a Middle Permian series: International Geology Review, v. 34, pp. 857-888.

Khain, V. E., 1985, Geology of the U.S.S.R., First Part, Old Cratons and Paleozoic Fold Belts: Gebrnder Borntraeger, Berlin, Stuttgart, 272p.

King, P. B., 1931, Geology of the Glass Mountains, Texas; part I, Descriptive geology: University of Texas Bulletin, 3038, 167p.

King, R. E., 1931, The geology of the Glass Mountains, part II, Faunal summary and correlation of the Permian formations with description of the Brachiopoda: University of Texas Bulletin 3042, 245p.

Kotlyar, G. B., and Stepanov, D. L. (eds.), 1984, Osnovnye Cherty Stratigraffii Permskoi Sistemy SSSR: Trudy Geologicheskii Institut Leningrad «Nedra» Leningradskoe Otdelenie, Novaya Seriya Tom 286, 280p.

Mann, K. O.,and Lane,R. H., 1995, Graphic correlation: a powerful stratigraphic technique comes of age, in Mann, K. O., Lane, L. R., and Scholle, P. A., eds., Graphic Correlation: SEPM Society for Sedimentary Geology Special Publication No. 53, pp. 3-13.

Nalivkin, D. V., 1962, Geology of the U.S.S.R.: University of Toronto Press, $855 \mathrm{p}$.

Remane, J., Bassett, M. G., Cowie, J. W., Gohrbandt, K. H., Lane, H. R., and Naiwen, W., 1996, Guidelines for the establishment of global chronostratigraphic standards by the International Commission on Stratigraphy (ICS) (Revised): Permophiles, no. 29, pp. 25-29.

Ross, C. A., 1960, Fusulinids from the Hess Member of the Leonard Formation, Leonard Series (Permian), Glass Mountains, Texas: Contributions from the Cushman Foundation for Foraminiferal Research, v. 11, Pt. 4, pp. 117-133.

Ross, C. A., 1962, Fusulinids from the Leonard Formation (Permian), western Glass Mountains, Texas: Contributions from the Cushman Foundation of Foraminiferal Research: v. 13, Pt. 1, pp. 1-21.

Ross, C. A., 1963a, Fusulinids from the Word Formation (Permian), Glass Mountains, Texas: Contributions from the Cushman Foundation for Foraminiferal Research, v. 14, Pt. 1, pp. 17-31.

Ross, C. A., 1963b, Standard Wolfcampian Series (Permian), Glass Mountains, Texas: Geological Society of America Memoir 88, 205p.

Ross, C. A., 1964, Two significant fusulinid genera from the Word Formation (Permian), Texas: Journal of Paleontology, v. 38, pp. 311-315.

Ross, C. A., 1987, Leonardian Series (Permian), Glass Mountains, West Texas, in, Cromwell, C., and Mazzullo, L., eds., The Leonardian facies in W. Texas and S.E. New Mexico and guidebook to the Glass Mountains, 
West Texas: 1987 Permian Basin Section Society of Economic Paleontologists and Mineralogists Publication 87-27, pp. 25-33.

Ross, C. A., and Ross, J. R. P., 1994, Permian sequence stratigraphy, in, Scholle, P. A., Peryt, T. M., and Ulmer-Scholle, D. S., eds., The Permian of Northern Pangea, Vol. 1, Springer-Verlag, Berlin, Heidelberg, New York, pp. 98-123.

Shaw, A. B., 1964, Time in Stratigraphy: McGraw Hill, New York, 365p.

Wardlaw, B. R., 1996, Range charts for the Permian of West Texas, in, Guadalupian II, Abstracts and Proceedings of the Second International Guadalupian Symposium, Sul Ross University, Alpine, Texas, pp. 40-60.

Wardlaw, B. R., and Grant, R. E., 1987, Conodont biostratigraphy of the Cathedral Mountain and Road Canyon formations, Glass Mountains, West Texas, in, Cromwell, D., and Mazzullo, L. J., eds., The Leonardian facies in West Texas and Southeast New Mexico and guidebook to the Glass Mountains, West Texas: 1987 Permian Basin Section, Society of Economic Paleontologists and Mineralogists Publication 87-27, pp. 6366.

Wardlaw, B. R., and Grant, R. E., 1989, Conodont biostratigraphy of the Permian Road Canyon Formation, Glass Mountains, Texas: United States Geological Survey Bulletin 1895, Shorter Contributions to Paleontology and Stratigraphy, pp. A1-A18.

Yang-Zhendong, 1993, Fusulinid paleontology and biostratigraphy of the Middle Permian (Guadalupian) strata of the Glass Mountains and Del Norte Mountains, West Texas: Unpub. Ph.D. dissertation, Texas A\&M University, College Station, 230p.

Yugan, J., Wardlaw, B. R., Glenister, B. F., and Kotlyar, G. V., 1997, Permian chronostratigraphic subdivisions: Episodes, v. 20, pp. 10-15.
Stephen L. Benoist is a Postdoctoral researcher at Louisiana State University (LSU), Baton Rouge, Louisiana US. In addition to managing LSU's Paleomagnetism Lab, his primary research duty at $L S U$ involves the integration of magnetic susceptibility data with biostratigraphic data using graphic correlation. His research efforts have focused on Neolithic cave deposits of southern Europe, Devonian sections of Morocco and Europe, and Carboniferous-Permian sections of the southwestern United States.

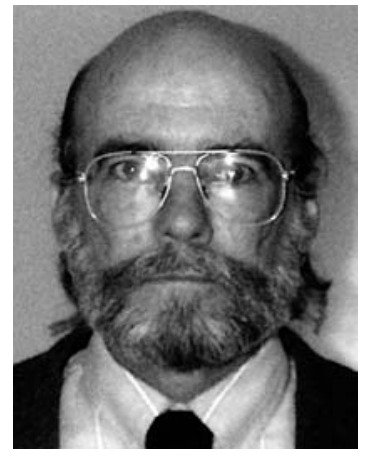

\section{Hutchison 'Young Scientist' Fund}

William Watt Hutchison, "Hutch" to his many friends around the world, was a Scots-born Canadian geologist who served Canada and the IUGS in myriad dynamic and creative ways. Most notably, he served as the IUGS Secretary General (1976-1980) at a pivotal time in its history, and as IUGS President (1984-1987). The same boundless energy, enthusiasm, skill in communications, and ability to foster teamwork that characterized his work with the IUGS also carried him to preeminent scientific administrative positions in the Canadian Government, where he served as Director General of the Geological Survey of Canada and as Assistant Deputy Minister of Earth Sciences. His distinguished career was terminated in 1987 by his untimely death at the age of 52, following a painful struggle with cancer.

One of Hutch's last wishes was to establish under IUGS auspices a memorial foundation intended to promote the professional growth of deserving, meritorious young scientists from around the world by supporting their participation in important IUGS-sponsored conferences.

The Hutchison "Young Scientist Foundation" is a worthy cause that honors a fine, caring man and a distinguished, public-spirited scientist and administrator. The foundation also celebrates and promotes those things that gave Hutch the most professional satisfaction: geology, international scientific collaboration, and stimulating young minds.

The IUGS welcomes contributions to the Hutchison "Young Scientist Foundation." Please send donations to:

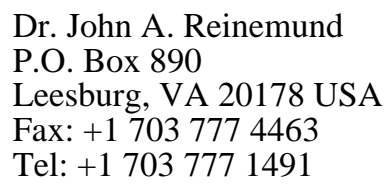

Checks in US dollars or Visa/Mastercard (please include account number and expiration date) are preferred in order to avoid the high cost of currency conversions. Residents of the U.S.A. are reminded that charitable gifts of this nature are tax deductible. 